MATTERS ARISING

\section{Management of knee osteoarthritis}

I read with great interest Dr Jawad's letter and the authors' reply about the EULAR recommendations for the management of knee osteoarthritis (OA). ${ }^{12}$

As a member of the ESCISIT task force I feel free to discuss some of the issues raised by Dr Jawad and to give further arguments for the accuracy of the recommendations developed by the group of European experts.

Although most points of criticism were answered by $M$ Dougados and $M$ Doherty it seems to me that treatment of knee OA with symptomatic slow acting drugs in osteoarthritis (SYSADOA) and cyclo-oxygenase-2 (COX-2) inhibitors needs to be discussed in a different way in the light of recent publications.

With respect to SYSADOA, the statement that these substances may modify structure has been strengthened by the publication of Reginster et al, in which glucosamine sulphate (GS) treatment was proved to exert a significant decrease in joint space narrowing compared with placebo during a three year period, indicating the disease modifying effect of GS for the first time. ${ }^{4}$ Moreover, symptomatic efficacy was shown using the WOMAC index as an outcome measure.

Other publications dealing with possible disease modifying properties of hyaluronic acid are well known, ${ }^{5}$ and trials investigating the same issue for chondroitin sulphate (CS) are currently underway. Two meta-analyses ${ }^{6}$ ? as well as controlled trials have provided evidence for the symptomatic efficacy of GS and CS and proved their overall excellent tolerability, when compared with treatment with non-steroidal antirheumatic drugs (NSAIDs).

With respect to COX-2 inhibitors, to my knowledge no publication exists to show that COX-2 inhibitors, such as Rofecoxib and Celecoxib, are more efficacious than classical NSAIDs. On the other hand, all the studies indicate better gastrointestinal tolerability of both these new compounds, but some severe gastrointestinal toxicity and dyspepsia, comparable with classical NSAIDs, has been noticed. ${ }^{89}$ When dyspepsia occurs it is not possible to predict erosions or an ulcer and, therefore, endoscopy has to be performed if epigastralgia occurs. This reduces the potential for cost saving with the new compounds and is inconvenient for patients. Thus the advantages of COX-2 inhibitors remain doubtful, taking into account the costs of these compounds, but should be considered carefully in the future.

It is obviously necessary to develop and adapt treatment recommendations according to upcoming knowledge all the time. The EULAR recommendations for the treatment of knee OA, however, at the time they were written seemed to summarise all the therapeutic options, including nonpharmacological and surgical options, accurately, even in the light of publications appearing after the end of the literature search in December 1998.

Dr Leeb is currently taking part in a trial focused on the disease modifying ability of CS, sponsored by IBSA.
B F LEEB

Lower Austrian Centre for Rheumatology, Stockerau Hospital, A-2000 Stockerau, Landstrasse 18, Austria

leeb.khstockerau@aon.at

1 Jawad ASM. EULAR recommendations for the management of knee osteoarthritis. Ann Rheum Dis 2001;60:540

2 Dougados M, Doherty M. EULAR recommendations for the management of knee osteoarthritis - reply. Ann Rheum Dis 2001;60:540.

3 Pendleton A, Arden N, Dougados M, Doherty $\mathrm{M}$, Bannwarth B, Bijlsma JWJ, et al. EULAR recommendations for the management of knee osteoarthritis. Report of a task force of the Standing Committee for International Clinical Studies Including Therapeutic Trials (ESCISIT). Ann Rheum Dis 2000;59:936-44.

4 Reginster JY, Deroisy R, Rovati LC, Lee RL, Lejeune E, Bruyere $\mathrm{O}$, et al. Long-term effects of glucosamine sulphate on osteoarthritis progression: a randomised, placebo controlled, trial. Lancet 2001;357:251-6.

5 Listrat V, Ayral X, Patarnello F, Bonvalet JP, Simonnet J, Amor B, et al. Arthroscopic evaluation of potential structure modifying activity of tion of potential structure modifying activity of hyaluronan (Hyalgan $(\mathbb{R})$ in osteoarthritis of the

knee. Osteoarthritis Cartilage 1997;5:153-60.

Leeb BF, Schweitzer H, Montag K, Smolen JS A metaanalysis of chondroitin sulfate in the treatment of

7 McAlindon TE, LaValley MP, Gulin JP, Felson DT. Glucosamine and chondroitin for the treatment of osteoarthritis: a systemic quality assessment and meta-analysis. JAMA 2000; 283:1469-75

8 Siverstein FE, Faich G, Goldstein JL, Simon LS, Pincus T, Whelton A, et al. Gastrointestinal toxicity with celecoxib vs nonsteroidal antiinflammatory drugs for osteoarthritis and rheumatoid arthritis: the CLASS study. A randomized controlled trial. Celecoxib Longterm Arthritis Safety Study. JAMA 2000;284 1247-55

9 Watson DJ, Harper SE, Zhao PL, Quan H, Bolognese JA, Simon TJ. Gastrointestinal tolerability of the selective cyclooxygenase-2 (COX-2) inhibitor rofecoxib compared with nonselective COX-1 and COX-2 inhibitors in osteoarthritis. Arch Intern Med 2000;160: 2998-3003.

\section{Author's reply}

I thank Dr Leeb for his interest in my recent letter about the EULAR recommendations. ${ }^{1}$ The recent large, randomised, placebo controlled, double blind, prospective trial had shown that glucosamine sulphate (GS) treatment resulted in significantly less medial joint space narrowing of the knee, in addition to significant improvements in pain and disability, which were sustained for the three year duration of the study. However, the general correlation between symptoms and structural changes was poor. ${ }^{2}$ The symptoms of patients with severe joint space narrowing receiving GS did improve, but this was not associated with slowing down of radiographic structure impairment. Further studies with longer follow up are needed to assess whether these changes are predictive of further clinical progression of osteoarthritis.

The year 2000 meta-analysis of the six best designed trials of GS for osteoarthritis reported two possible limitations among the analysed studies. Firstly, only one study had adequately assured randomised allocation. ${ }^{3}$ The second limitation was that authors were often affiliated with the manufacturers of the product tested. Among the six studies analysed, the one assigned the highest quality score reported the smallest effect. ${ }^{4}$

A meta-analysis of seven randomised controlled trials of chondroitin sulphate (CS) in osteoarthritis had shown better pain relief with CS than with placebo at six months; however, no dose effect was noted (for example, 2000 and $800 \mathrm{mg} /$ day were similarly effective). ${ }^{5}$ A large long term, double blind, randomised controlled trial is needed to confirm the symptomatic benefit of CS in osteoarthritis

The main advantage of GS and CS is their safety, and they are certainly more safe than non-selective, non-steroidal anti-inflammatory drugs (NSAIDs), especially in their effect on the gastrointestinal tract.

With regards to COX-1 sparing NSAIDs, I agree with Dr Leeb, that there is no evidence for any important differences in efficacy between them and non-selective NSAIDs. ${ }^{6}$ Systematic reviews have also found no important differences in efficacy between different NSAIDs, but found differences in side effects related to increased doses of NSAIDs and the nature of the NSAID itself. ${ }^{8}$ The principal benefit of COX-1 sparing NSAIDs is that they produce analgesia and antiinflammatory effects comparable with those of the non-selective NSAIDs but cause fewer symptomatic gastric and duodenal ulcers and fewer gastrointestinal symptoms. ${ }^{67}$ The EULAR recommendations need to be revised in the near future.

$$
\begin{array}{r}
\text { A S M JAWAD } \\
\text { The Royal London Hospital, } \\
\text { Bancroft Road, }
\end{array}
$$

London E1 4DG, UK

1 Jawad ASM. EULAR recommendations for the management of knee osteoarthritis. Ann Rheum Dis 2001;60:540.

2 Reginster JY, Deroisy R, Rovati LC, Lee RL, Lejeune E, Bruyere O, et al. Long-term effects of glucosamine sulphate on osteoarthritis progression: a randomised, placebo controlled progression: a randomised, place

3 McAlindon TE, LaValley MP, Gulin JP, Felson DT. Glucosamine and chondroitin for the treatment of osteoarthritis: a systemic quality assessment and meta-analysis. JAMA 2000: 283:1469-75

4 Noack W, Fischer M, Forster KK, Rovatic LC, Setnikar 1. Glucosamine sulfate in osteoarthritis of the knee. Osteoarthritis Cartilage 1994;2: 51-9.

5 Leeb BF, Schweitzer H, Montag K, Smolen JS. A meta-analysis of chondroitin sulfate in the treatment of osteoarthritis. J Rheumatol 2000; 27:205-11.

6 Silverstein FE, Faich G, Goldstein JL, Simon LS, Pincus T, Whelton A, et al. Gastrointestinal toxicity with celecoxib vs nonsteroidal antiinflammatory drugs for osteoarthritis and rheumatoid arthritis: the CLASS study: a randomized controlled trial celecoxib longterm arthritis safety study. JAMA 2000;284: term arth

7 Bombardier C, Laine L, Reicin A, Shapiro D, Burgos-Vargas R, Davis B, et al. Comparison of upper gastrointestinal toxicity of rofecoxib and naproxen in patients with rheumatoid arthritis. N Engl J Med 2000;343:1520-8.

8 Gotzsche P. Non-steroidal anti-inflammatory drugs. Clinical Evidence 2000;4:641-8.

LETTERS TO THE EDITOR

\section{Fenofibrate: a new treatment for hyperuricaemia and gout?}

Allopurinol is the most commonly used drug in the prevention of gout owing to its efficacy and good tolerability. However, some patients still experience hyperuricaemia or gout, or 
both, despite allopurinol treatment. Fenofibrate is an established treatment for many common lipid disorders and is unique amongst the fibric acid derivatives because of its ability to lower serum urate by increasing renal uric acid clearance. ${ }^{1}$ This urate lowering property has been demonstrated in healthy volunteers ${ }^{1}$ and in diabetic and non-diabetic patients with hyperlipidaemia. ${ }^{2-4}$

To date, no studies have specifically evaluated the urate lowering effect of fenofibrate in patients with hyperuricaemia receiving established treatment with allopurinol. We report three cases in which micronised fenofibrate, a single dose formulation of the drug, was initiated in patients with established gout and hyperuricaemia, with and without coexisting hyperlipidaemia. Two of these patients were already receiving established allopurinol treatment.

\section{PATIENT 1}

A 74 year old Chinese man had recurrent attacks of gout affecting the metatarsophalangeal joints every two to three months for the preceding three years. He had treated hypertension and polygenic hypercholesterolaemia and had been taking allopurinol $300 \mathrm{mg}$ daily for three months, which produced a serum urate range between 0.40 and $0.44 \mathrm{mmol} / 1$ The 24 hour renal uric acid clearance was 6.4 $\mathrm{ml} / \mathrm{min}$ (reference range $6-11$ ). Treatment was started with micronised fenofibrate 200 $\mathrm{mg}$ daily, and three weeks later his urate had fallen by $35 \%$ to $0.26 \mathrm{mmol} / \mathrm{l}$, with the 24 hour uric acid clearance rising to $11.5 \mathrm{ml} / \mathrm{min}$ (table 1). Alkaline phosphatase activity fell from 77 to $44 \mathrm{U} / 1$, confirming compliance with the fibrate treatment. A temporary withdrawal of fenofibrate treatment for three weeks resulted in an increase in urate to 0.39 $\mathrm{mmol} / \mathrm{l}$. Fenofibrate was restarted and he continues to take it in combination with allopurinol. No acute attacks of gout have occurred since fenofibrate was started.

\section{PATIENT 2}

A 49 year old white man had recurrent episodes of gout affecting the metatarsophalangeal and knee joints despite having had allopurinol increased from 300 to $600 \mathrm{mg}$ daily six months previously. These episodes occurred every two to three months and usually responded to a short course of indometacin. He was clinically obese but did not drink alcohol and was complying with a low purine diet. His serum urate was 0.58 $\mathrm{mmol} / \mathrm{l}$, and when determined three weeks later it measured $0.61 \mathrm{mmol} / 1$ with a corresponding 24 hour uric acid clearance of $8.0 \mathrm{ml} / \mathrm{min}$. Micronised fenofibrate $200 \mathrm{mg}$ daily was added to the allopurinol treatment and three weeks later the serum urate had been reduced by $39 \%$ to $0.37 \mathrm{mmol} / \mathrm{l}$, with an associated doubling in uric acid clearance (table 1). Additionally, serum lipids were reduced, together with a reduction in alkaline phosphatase activity. Fenofibrate was temporarily discontinued and the serum urate returned to a higher level. It has been restarted and no further attacks of gout have occurred in 12 months of follow up.

\section{PATIENT 3}

A 43 year old white man was referred with recurrent episodes of acute gout affecting the ankle and toe interphalangeal joints every four to six weeks. There was no other medical history of note, but there was a family history of gout. During his most recent attack of gout, the serum urate was $0.35 \mathrm{mmol} / \mathrm{l}$. When repeated after one month the urate was 0.48 $\mathrm{mmol} / \mathrm{l}$ with a total cholesterol of $8.2 \mathrm{mmol} / \mathrm{l}$ and triglycerides $2.4 \mathrm{mmol} / 1$. Treatment with micronised fenofibrate was started, and three weeks later his urate was $0.34 \mathrm{mmol} / 1$ (a $29 \%$ reduction). Both cholesterol and triglyceride concentrations were also reduced to 7.3 $\mathrm{mmol} / 1$ and $1.5 \mathrm{mmol} / 1$ respectively, and the uric acid clearance rose from 5.8 to 11.2 $\mathrm{ml} / \mathrm{min}$. Alkaline phosphatase activity fell from 82 to $72 \mathrm{U} / 1$. He continues to receive micronised fenofibrate $200 \mathrm{mg}$ daily, and further attacks of acute gout have not recurred over a six month follow up period.

We have reported three cases of hyperuricaemia in association with recurrent episodes of gout, in which micronised fenofibrate was effective in further lowering serum urate and in reducing the frequency of gouty attacks. Importantly, two of these patients were already being treated with allopurinol. The urate effect has been previously shown in patients with hyperlipidaemia treated with fenofibrate,$^{2-4}$ but this report demonstrates its efficacy specifically in patients with hyperuricaemia and gout. The reductions in urate shown in these three patients treated with fenofibrate were of similar magnitude to those seen in patients given the drug who had hyperlipidaemia with or without type 2 diabetes and who were not receiving allopurinol treatment. ${ }^{2-4}$ The doubling in uric acid clearance, which was reversed in two of the patients when fenofibrate was withdrawn, indicates a drug-specific renal effect. The particularly large reduction in serum urate in the second patient was perhaps a little surprising, but we are certain that this was largely a fenofibrate effect because a rise in uric acid clearance was seen, together with reductions in alkaline phosphatase activity and serum lipids. Furthermore, he denied any significant lifestyle changes during this period.

Importantly, none of these patients has had any adverse effect, in particular a flare of gout, while taking fenofibrate. Only the second patient wished to take a prophylactic drug against this. Each was advised to

Table 1 Effect of the addition and withdrawal of fenofibrate on serum urate, serum lipids, and uric acid clearance in two patients treated with allopurinol

\begin{tabular}{llll}
\hline & $\begin{array}{l}\text { Allopurinol } \\
\text { (alone) }\end{array}$ & $\begin{array}{l}\text { Allopurinol }+ \\
\text { fenofibrate combination }\end{array}$ & $\begin{array}{l}\text { Allopurinol } \\
\text { (fenofibrate withdrawn) }\end{array}$ \\
\hline Patient 1 & 0.40 & 0.26 & 0.39 \\
$\quad$ Serum urate (mmol/1) & 6.4 & 11.5 & 4.7 \\
$\quad$ Uric acid clearance $(\mathrm{ml} / \mathrm{min})$ & 5.9 & 7.4 \\
Total cholesterol $(\mathrm{mmol} / \mathrm{l})$ & 7.4 & 1.5 & 2.4 \\
$\quad$ Serum triglycerides $(\mathrm{mmol} / \mathrm{l})$ & 1.3 & 0.37 & 0.46 \\
Patient 2 & 0.61 & 16.4 & 9.0 \\
Serum urate (mmol/1) & 8.0 & 4.9 & 5.2 \\
Uric acid clearance $(\mathrm{ml} / \mathrm{min})$ & 5.4 & 2.1 & 1.9 \\
Total cholesterol $(\mathrm{mmol} / \mathrm{l})$ & 2.3 & & \\
Serum triglyceride $(\mathrm{mmol} / \mathrm{l})$ & &
\end{tabular}

increase their fluid intake at the time, though uric acid urolithiasis has not been reported previously with fenofibrate. There has been no evidence of an adverse interaction between allopurinol and fenofibrate in the first two patients, who both continue to take this combination. Although unlikely, potential adverse reactions and interactions should be borne in mind when fenofibrate is prescribed for patients with hyperuricaemia, and measures taken to prevent them considered.

Serum urate is often raised in hyperlipidaemic patients, particularly those with hypertriglyceridaemia. ${ }^{56}$ The mechanism for the relationship is not clearly defined, though the association may arise through common environmental and genetic risk factors shared by hyperuricaemia and hypertriglyceridaemia, such as obesity and excessive alcohol consumption, or through a primary metabolic defect. $^{5}$ In contrast, hypertriglyceridaemia has been reported to occur in up to $60 \%$ of patients with gout. ${ }^{78}$

Hyperlipidaemia is common in the UK population and is a major risk factor for cardiovascular disease. The relationship between ischaemic heart disease and serum urate is controversial. It has recently been shown that hyperuricaemia may be an independent risk factor for ischaemic heart disease, ${ }^{9}$ though other studies have not supported this observation..$^{10} \mathrm{~A}$ reduction in both hyperlipidaemia and serum urate might therefore be desirable in order to reduce cardiovascular risk. Fenofibrate may offer a useful dual effect in this respect, so potentially reducing the need for multiple drug treatments. This specific role for the drug is an important area in need of further study.

We have confirmed in our three cases that fenofibrate effectively lowers serum urate by a uricosuric effect. Expected reductions in lipids were also seen, suggesting a specific clinical role of this drug in the treatment of the common metabolic abnormality of coexisting hyperuricaemia and hyperlipidaemia. Further, it may be considered in combination with allopurinol in patients with hyperuricaemia who still experience gout despite a lowering in their serum urate. We would encourage further studies to be performed to evaluate the role of fenofibrate alone or in combination with allopurinol in the treatment of gout and hyperuricaemia. Gout remains a common problem in the community - fenofibrate appears to be a long awaited agent with great potential for use in this condition.

A L HEPBURN Rheumatology Section, Imperial College School of Medicine, Hammersmith Hospital, Du Cane Road, London W12 ONN, UK

S A KAYE Rheumatology Department, Chelsea and Westminster Hospital, Fulham Road, London SW10 9NH, UK

M D FEHER Lipid Clinic, Chelsea and Westminster Hospital

Correspondence to: Dr Hepburn

1 Desager J-P, Hulhoven R, Harvengt C. Uricosuric effect of fenofibrate in healthy volunteers. $J$ Clin Pharmacol 1980;20:560-4

2 Harvengt C, Heller F, Desager J-P. Hypolipidaemic and hypouricaemic action of fenofibrate in various types of hyperlipoproteinaemia. Artery 1980;7:73-82. 
3 Bastow MD, Durrington PN, Ishola M. Hypertriglyceridaemia and hyperuricaemia: effects of wo fibric acid derivatives (bezafibrate an fenofibrate) in a double-blind placebocontrolled trial. Metabolism 1988;37:217-20.

4 Feher MD, Calake M, Foxton J, Cox A, Packard CJ. Atherogenic lipoprotein phenotype in type 2 diabetes: reversal with micronised fenofibrate. Diabetes Metab Rev 1999;15:395-9.

5 Fox HF, John D, DeBruyne S, Dwosh I, Marliss EB. Hyperuricaemia and hypertriglyceridaemia: metabolic basis for the association. Metabolism 1985;34:741-6.

6 Emmerson B. Hyperlipidaemia in hyperuricaemia and gout. Ann Rheum Dis 1998;57:50910.

7 Berkowitz D. Blood lipid and uric acid interrelationships. JAMA 1964;190:856-8.

8 Feldman EB, Wallace SL. Hypertriglyceridaemia in gout. Circulation 1964;29:508-13.

9 Fang J, Alderman MH. Serum uric acid and cardiovascular mortality. The NHANES 1/epidemiologic follow-up study 1971-92. JAMA 2000;283:2404-10

10 Moriarity JT, Folsom AR, Iribarren C, Nieto FJ, Rosamond WD. Serum uric acid and the risk of coronary heart disease: Atherosclerosis Risk in Communities (ARIC) Study. Ann Epidemiol 2000;10:136-43.

\section{Effect of leeches therapy (Hirudo medicinalis) in painful osteoarthritis of the knee: a pilot study}

Leeches therapy was a mainstay in conventional treatment of pain and inflammatory diseases throughout antiquity until the 20th century. ${ }^{1-3}$ There is now renewed interest in leeches therapy in the field of complementary medicine. Sales of the four principal German traders have increased continuously throughout the past few years and led to an estimated 70000 treatments (350 000 leeches sold/ year, four to five used for each single treatment) yearly in Germany (Roth $M$, unpublished data). The majority of these

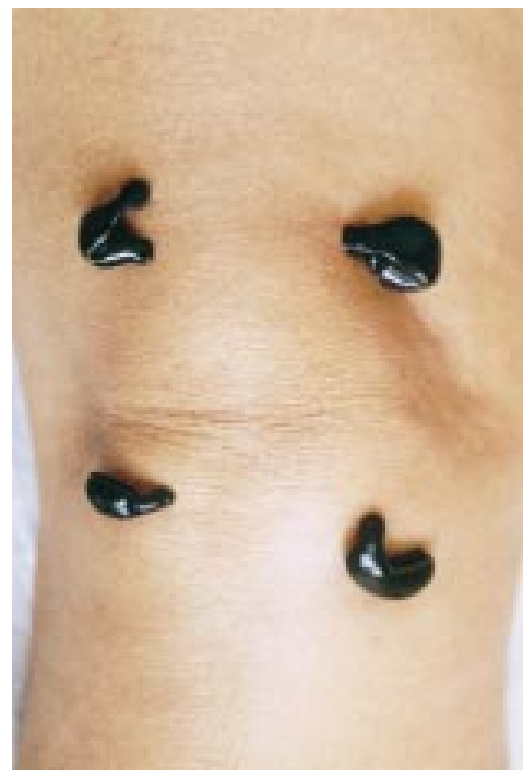

Figure 1 Treatment with four leeches at typical periarticular sites of the knee joint. treatments aim at pain reduction in regional pain syndromes, mostly for knee osteoarthritis. ${ }^{2}$ With the exception of its application in plastic surgery to maintain blood flow in congested skin flaps, ${ }^{45}$ treatment with leeches has, however, never been evaluated in clinical studies. We conducted a non-randomised controlled pilot study to assess the onset of action and the impact of leeches therapy as an adjunctive treatment in knee osteoarthritis.

From inpatients whose main diagnosis was severe chronic back pain, we recruited over a period of three months 16 consecutive patients with primary knee osteoarthritis. All patients had had persistent knee pain for more than six months and had definite radiographic signs of knee osteoarthritis without previous injury. Major exclusion criteria were treatment with anticoagulants, secondary osteoarthritis, substantial comorbidity, and intra-articular corticosteroids in the three preceding months. All patients had an in-hospital period of 14 days and received a health education programme, with focus on exercise, physiotherapy, relaxation techniques, and diet. Regular use of non-steroidal anti-inflammatory drugs was stopped throughout the study period.

After detailed information all patients were offered additional treatment with leeches. Ten patients (eight women, mean (SD) age 69 (9) years, mean body mass index (BMI) $28.0(4.6) \mathrm{kg} / \mathrm{m}^{2}$ ) agreed and were treated once with four leeches (Zaug $\mathrm{GmbH}$, Biebertal, Germany). Six controls (five women, mean age 68 (8) years, mean BMI 27.3 (3.0) $\mathrm{kg} / \mathrm{m}^{2}$ ) did not wish to be treated with leeches and were treated only conventionally. The leeches were applied by trained doctors topically at the painful knee joint (fig 1), and monitoring was carried out according to published recommendations. ${ }^{4}$ The primary outcome measure was a change in total knee pain score, assessed by visual analogue scale (VAS, $0=$ no pain, $10=$ extremely painful) for 10 days daily, starting three days before treatment and, additionally, in a follow up 28 days after treatment.

In comparison with the controls, leech application led to rapid relief of knee pain $(p<0.05$ three days after treatment, Wilcoxon two sample test), with most effect seen within 24 hours after application and sustained and clinical relevant improvement after four weeks ( $\mathrm{p}<0.05$, Wilcoxon matched pairs test) in the absence of complications (table 1).

The mean length of treatment was 80 minutes, and the procedure was well accepted. There were no serious adverse effects and no local infections. Patients described the initial leech bite as slightly painful. There are several explanations for the observed treatment effect. The saliva of leeches contains a variety of substances such as hirudin, hyaluronidase, histamine-like vasodilators, collagenase, inhibitors of kallikrein and superoxide production, and poorly characterised anaesthetic and analgesic compounds. ${ }^{6-8}$ Therefore, a regional analgesic and antiphlogistic effect by these substances enforced by hyaluronidase as well as counter-irritation might be possible. More importantly, we do not know the non-specific (placebo) effects of this unusual treatment. We observed an apparent mood enhancement during leeching which might explain the observed rapid treatment effect, but hardly explains the lasting pain relief after four weeks.

We recognise the limitations of the present study design as the non-random allocation of treatment, no assessment of functional improvement, and the small sample size. However, we regard the observed clear treatment effect as remarkable; treatment with leeches reduced pain significantly after three days and up to four weeks. The efficacy and safety of this traditional treatment in knee osteoarthritis should therefore be tested in larger randomised controlled trials.

The study was supported by Karl and Veronika Carstens Foundation, Germany.

$$
\begin{array}{r}
\text { A MICHALSEN } \\
\text { U DEUSE } \\
\text { T ESCH } \\
\text { G DOBOS } \\
\text { Kliniken Essen-Mitte, } \\
\text { Medicine, } \\
\text { Department for Internal and Integrative } \\
\text { Am Deimelsberg 34a, } \\
\text { D-45276 Essen, Germany } \\
\text { S MOEBUS } \\
\text { Institute for Medical Informatics, } \\
\text { Biometry and Epidemiology, } \\
\text { Medical Faculty, } \\
\text { University of Essen, } \\
\text { Hufelandstrasse 55, } \\
\text { D-45147 Essen, Germany }
\end{array}
$$

Correspondence to: Privat Dozent Dr med G Dobos gustav.dobos@uni-essen.de

1 Giacometti L. Leeching in the twentieth century. Am J Cardiol 1987;60:1128-31.

2 Müller IW. Handbuch der Blutegeltherapie. Heidelberg: Haug, 2000.

3 Shah S. Why leeches influence my physical examination. Lancet 1998;352:2014-15.

4 Kraemer BA, Korber KE, Aquino TI, Engleman A. Use of leeches in plastic and reconstructive surgery: a review. J Reconstr Microsurg 1988;4:381-6.

5 Weinfeld AB, Yuksel E, Boutros S, Gura DH, Akyurek M, Friedman JD. Clinical and scientific Akyurek M, Friedman JD. Clinical and scientific ment of acute venous congestion: an updated review. Ann Plast Surg 2000;45:207-12.

6 Sawyer RT. Leech biology and behaviour. New Sawyer RT. Leech biology and behaviour
York: Oxford University Press, 1986.

7 Rigbi M, Levy HZ, Iraqi F, Teitelbaum M, Orevi M, Alajoutsijarvi A, et al. The saliva of the medicinal leech Hirudo medicinalis -I. Biochemical characterisation of the high molecular weight fraction. Comp Biochem Physiol

\begin{tabular}{|c|c|c|c|c|c|c|}
\hline & Baseline & Day 3 & Day 4 & Day 6 & Day 10 & Day 28 \\
\hline Leeches $(n=10)$ & $7.4(6.3$ to 8.5$)$ & $7.2(6.2$ to 8.2$)$ & $4.1(2.8$ to 5.4$)$ & $2.4(1.2 \text { to } 3.6)^{\star}$ & $1.3(0.5 \text { to } 2.8)^{\star}$ & $1.0(0.5 \text { to } 1.5)^{\star}$ \\
\hline Controls $(n=6)$ & 6.3 (4.8 to 7.8$)$ & $5.8(4.3$ to 7.4$)$ & 5.8 (4.4 to 7.3$)$ & $5.2(3.6$ to 6.7$)$ & $5.2(3.8$ to 6.5$)$ & $4.8(3.8$ to 5.9$)$ \\
\hline
\end{tabular}
B Biochem Mol Biol 1987;87:567-73.

8 Orevi M, Rigbi M, Hy-Am E, Matzner Y, Eldor A. A potent inhibitor of platelet activating factor from the saliva of the leech Hirudo medicinalis. Prostaglandins 1992;43:483-95.

\section{Clinical features of several connective tissue diseases with anti-Golgi antibody}

Rodriguez et al were the first to report autoantibodies directed against the Golgi complex identified in the serum of a patient with Sjögren's syndrome (SS). ${ }^{1}$ Since then, several isolated reports have described the

Table 1 Pain ratings (VAS, $0=$ no pain, $10=$ extremely painful) in patients with leech treatment and in controls; mean score and $95 \%$ confidence interval $(\bar{x} \pm 1.96$ SEM

Days 1-3: Pretreatment observation period. First rating after leeches treatment on day 4 . Further ratings at days 6,10 , and 28.

${ }^{\star} \mathrm{p}<0.05$ between group differences. 
presence of anti-Golgi antibodies (AGAs) in several connective tissue diseases (CTDs). ${ }^{1-7}$ In addition, immunoblotting and immunoprecipitation studies have suggested that there are at least 14 different Golgi complex autoantigens, and their molecular masses range from 35 to $260 \mathrm{kDa} .^{5}$ However, few reports describe the association between the clinical features of CTD and AGAs. In this letter we present a case of rheumatoid arthritis (RA) associated with AGAs and review several reported cases.

The patient was a woman born in 1939 who developed seropositive RA in 1990. She was admitted to our hospital in March 1998 because of high grade fever, cough, sore throat, chest pain, and severe arthralgia. Systemic laboratory examination disclosed no antinuclear antibody, anti-DNA antibody, or anti-Jo-1 antibody. Anti-SS-A antibody was positive. Chest computed tomography showed interstitial pneumonia with fine reticular shadow and honeycombing in both lower lobes. Physical examination showed fine crackles in both lung fields. A laboratory examination showed raised $\mathrm{C}$ reactive protein $(78 \mathrm{mg} / \mathrm{l})$, serum aspartate aminotransferase $(62 \mathrm{U} / \mathrm{l})$, serum alanine aminotransferase (52 $\mathrm{U} / \mathrm{l})$, creatine kinase (236 U/1), lactate dehydrogenase $(527 \mathrm{U} / 1), \operatorname{IgA}(5.6 \mathrm{~g} / 1)$, and IgG $(26.2 \mathrm{~g} / \mathrm{l})$. Mild interstitial lymphocytic infiltration was demonstrated in a muscle biopsy specimen. Therefore, a clinical diagnosis of RA, polymyositis complicated with interstitial pneumonia was made, in addition to a suspicion of SS

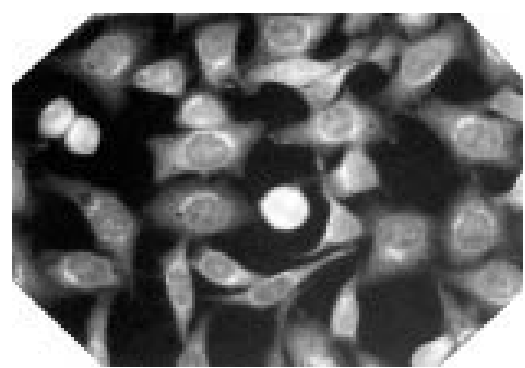

Figure 1 Indirect immunofluorescence staining of anti-Golgi antibodies just outside the nuclear membrane of Hep-2 cells with the patient's serum. Crescent-shaped cytoplasmic organella that surround the nuclear membrane of Hep-2 cells are clearly shown, and considered to be Golgi apparatus. Linear-shaped cytoplasmic filaments are also seen and considered to be cytokeratins.
Indirect immunofluorescence stained by the patient's serum (fig 1) showed crescentshaped cytoplasmic organella that surrounded the nuclear membrane of Hep-2 cells, and these were considered to be Golgi apparatus. Linear-shaped cytoplasmic filaments were also seen and considered to be cytokeratins. Western blotting analysis against lung epithelial cell line (A549) and hepatoma cell line (HLE) showed that proteins of $58 \mathrm{kDa}, 54 \mathrm{kDa}$, and $50 \mathrm{kDa}$ were stained by the patient's serum. The 58 and 50 $\mathrm{kDa}$ proteins were considered to be Golgi antigens, and the $54 \mathrm{kDa}$ protein was considered to be cytokeratin 8 . Tables 1 outlines the clinical features of the 15 patients with AGA reviewed. ${ }^{1-7}$ The patients comprised 11 women, three men, and in one case the sex of the patient was not given. Western immunoblot analyses disclosed several antigens with molecular weights ranging from 50 to 230 $\mathrm{kDa}$.

To date, several possible clinical correlations have been identified in patients with AGA. However, the clinical associations are different; in Blaschek's report, the incidence of an association with SS was shown to be significantly higher than in patients with other CTDs, ${ }^{8}$ whereas Fritzler's report suggested a strong association with systemic lupus erythematosus (SLE). ${ }^{2}$ Our present letter also showed that AGA was detected in patients with SS, SLE, and RA. As clinical features, our patient had mild liver dysfunction as indicated by raised liver enzymes and interstitial pneumonia. Fritzler et al have also reported that 5/8 patients with AGA had liver dysfunction. ${ }^{2}$ In addition, several patients had cardiopulmonary diseases, including pulmonary fibrosis as shown in our case. ${ }^{23}$ Because we have shown the existence of antigens in type II epithelial cells (A549) as well as in hepatoma cell lines (HLE), it was speculated that the existence of AGA might be related to liver dysfunction and the onset of interstitial pneumonia. Furthermore, detection of AGA in a patient with RA might also have potential pathogenic implications, because the Golgi apparatus participates in terminal protein glycosylation whereas high levels of agalactosyl IgG occur in RA and correlate with disease activity. ${ }^{9}$

In conclusion, our case and those of previous reports suggest that although antigens of AGA have diversity and heterogeneity, AGA might be pathogenetically related to some clinical features of CTDs.

\author{
Y YANG \\ J FUIITA \\ M TOKUDA \\ $S$ BANDOH \\ T ISHIDA \\ First Department of Internal Medicine, \\ Kagawa Medical University, \\ Kagawa, Japan \\ M MUROTA \\ $\mathrm{F}$ WU \\ M NISHIOKA \\ Third Department of Internal Medicine, \\ Kagawa Medical University, \\ Kagawa, Fapan
}

Correspondence to: Dr J Fujita, First Department of Internal Medicine, Kagawa Medical University, 1750-1, Miki-cho, Kita-gun, Kagawa, 761-0793, Japan

jiro@kms.ac.jp

1 Rodriguez JL, Gelpi C, Thomson TM, Real FJ, Fernandez J. Anti-golgi complex autoantibodies in a patient with Sjögren syndrome and lymphoma. Clin Exp Immunol 1982;49:57986.

2 Fritzler MJ, Etherington J, Sokoluk C, Kinsella TD, Valencia DW. Antibodies from patients with autoimmune disease react with a cytoplasmic antigen in the Golgi apparatus. J Immunol 1984;132:2904-8.

3 Rossie KM, Piesco NP, Charley MR, Oddis CV, Steen VD, Fratto J, et al. A monoclonal antibody recognizing Golgi apparatus produced using affinity purified material from a patient with connective tissue disease. Scand J Rheumatol 1992;21:109-15.

4 Hong HS, Morshed SA, Tanaka S, Fujiwara T, Ikehara Y, Nishioka M. Anti-Golgi antibody in rheumatoid arthritis patients recognizes a novel rheumatoid arthritis patients recognizes a novel antigen of $79 \mathrm{kDa}$ (doublet) by we

5 Kooy J, Toh BH, Gleeson PA. Heterogeneity of human anti-Golgi auto-antibodies: reactivity human anti-Golgi auto-antibodies: reactivity with components from 35 to

6 Renier G, Rousselet MC, Carrere F, Croue A, Andre C, Oksman F, et al. Golgi autoantibodies and autoantigens. J Autoimmun 1994;7:13343.

7 Griffith KJ, Chan EK, Lung CC, Hamel JC, Guo X, Miyachi K, et al. Molecular cloning of a novel 97-kd Golgi complex autoantigen associated with Sjögren's syndrome. Arthritis Rheum 1997;40:1693-702.

8 Blaschek MA, Pennec YL, Simitzis AM, Le Goff P, Lamour A, Kerdraon G, et al. Anti-Golgi complex autoantibodies in patients with primary Sjögren's syndrome. Scand J

9 Rock GA, Lydyard PM, Stanford JL. A reappraisal of the evidence that rheumatoid reappraisal of the evidence that rheumatoid
arthritis and several other idiopathic diseases are slow bacterial infections. Ann Rheum Dis 1993;52:S30-8.

Table 1 Characteristics of patients with connective tissue diseases in whom anti-Golgi antibodies were detected

\begin{tabular}{|c|c|c|c|c|c|c|c|c|c|c|}
\hline Authors & Year & $\begin{array}{l}\text { Age } \\
\text { and sex }\end{array}$ & Background ${ }^{\star}$ & $\begin{array}{l}\text { Rheumatoid } \\
\text { factor }\end{array}$ & $\begin{array}{l}\text { Antinuclear } \\
\text { antibody }\end{array}$ & Arthritis & Cardiopulmonaryt & $\begin{array}{l}\text { Liver } \\
\text { dysfunction }\end{array}$ & $\begin{array}{l}\text { Molecular } \\
\text { weight }(k D a)\end{array}$ & References \\
\hline Rodriguez & 1982 & $38 \mathrm{~F}$ & SS + lymphoma & + & + & - & $\mathrm{ND} \ddagger$ & + & ND & 1 \\
\hline Fritzler & 1984 & $71 \mathrm{M}$ & SLE & ND & + & + & + & + & ND & 2 \\
\hline Fritzler & 1984 & $53 \mathrm{M}$ & SLE & ND & + & + & + & - & $\mathrm{ND}$ & 2 \\
\hline Fritzler & 1984 & $28 \mathrm{~F}$ & SLE & ND & + & + & + & - & ND & 2 \\
\hline Fritzler & 1984 & $22 \mathrm{~F}$ & SLE & ND & - & + & - & + & ND & 2 \\
\hline Fritzler & 1984 & $36 \mathrm{~F}$ & SLE & ND & - & + & - & - & ND & 2 \\
\hline Fritzler & 1984 & $25 \mathrm{M}$ & SLE + RA & ND & + & + & + & + & ND & 2 \\
\hline Fritzler & 1984 & $47 \mathrm{~F}$ & SS & ND & + & - & - & + & $\mathrm{ND}$ & 2 \\
\hline Rossie & 1992 & $75 \mathrm{~F}$ & $\begin{array}{l}\text { PM + SLE + } \\
\text { SS }\end{array}$ & - & + & + & + & - & 64,59 & 3 \\
\hline Hong & 1992 & $58 \mathrm{~F}$ & RA & + & + & ND & ND & + & 79 & 4 \\
\hline Hong & 1992 & $66 \mathrm{~F}$ & RA & + & + & ND & ND & + & 79 & 4 \\
\hline Kooy & 1994 & ND & SS & ND & + & ND & ND & ND & 230,120 & 5 \\
\hline Renier & 1994 & $67 \mathrm{~F}$ & RA & ND & - & + & - & - & 230 & 6 \\
\hline Griffith & 1997 & $39 \mathrm{~F}$ & Secondary SS & ND & ND & ND & ND & $\mathrm{ND}$ & 97 & 7 \\
\hline Yang & 2001 & $61 \mathrm{~F}$ & $\mathrm{RA}+\mathrm{PM}$ & + & - & + & + & + & 58,50 & This study \\
\hline Total cases $(\%)$ & & & & $4 / 5(80 \%)$ & $10 / 14(71 \%)$ & 9/11 (82\%) & $6 / 10(60 \%)$ & $8 / 13(62 \%)$ & & \\
\hline
\end{tabular}

*SS = Sjögren's syndrome; SLE = systemic lupus erythematosus; RA = rheumatoid arthritis; PM = polymyositis

†Cardiopulmonary parameters included pericarditis, pleuritis, and/or pulmonary fibrosis.

$\ddagger \mathrm{ND}=$ not described. 


\section{Serum procalcitonin measurement for detection of intercurrent infection in febrile patients with SLE}

It is sometimes difficult to distinguish infection from disease flare in febrile patients with systemic lupus erythematosus (SLE). Chill, leucocytosis, and increased $\mathrm{C}$ reactive protein (CRP) are known to be markers favouring infection. ${ }^{1}$ Procalcitonin (PCT) is the precursor of calcitonin and is synthesised in the parafollicular C cells of the thyroid. Serum PCT increases in severe bacterial or fungal infection but does not increase, or increases only slightly, in viral infections. ${ }^{23}$ The purpose of this study was to evaluate the usefulness of serum PCT in febrile episodes of patients with SLE to distinguish infection from disease flare.

We prospectively enrolled 19 patients with SLE with fever who were admitted to Seoul National University Hospital between October 1998 and April 1999. Fever was defined as an axillary temperature over $38^{\circ} \mathrm{C}$. Eleven patients with inactive SLE were enrolled as controls. Blood of the febrile lupus patients was withdrawn three times: on the day of the hospital visit, and after 24 hours and 48 hours. Another sample was withdrawn two weeks after defervescence to control infection or because of a decrease in lupus activity. At the detection of fever, blood cultures and other necessary cultures were performed with complete blood count, Westergren erythrocyte sedimentation rate (ESR), CRP, serum anti-dsDNA, complements (C3, C4), urine analysis, serum creatinine, and chest $x$ ray examination.

The patients were divided into groups on the basis of viral infection, non-viral infection, and lupus flare. Lupus flare was defined by the Systemic Lupus Erythematosus Disease Activity Index (SLEDAI ${ }^{4}$ as an increase of more than three points compared with the SLEDAI of the patient one month before the febrile period. Serum PCT was measured by an immunoluminometric assay (LUMItest, Brahms Diagnostika, Berlin). Twelve lupus patients were shown to have infection (nine non-viral, three viral infections) and seven patients had lupus flare. Non-viral infections consisted of urinary tract infection $(\mathrm{n}=3)$, sinusitis $(n=1)$, tuberculosis $(n=1)$, scrub typhus $(\mathrm{n}=1)$, pseudomembranous colitis $(\mathrm{n}=1)$, aspergillosis $(\mathrm{n}=1)$, and nocardiosis $(n=1)$. Viral infections were upper respiratory infection $(n=2)$ and gastroenteritis $(n=1)$.

The white cell count was higher in the group with non-viral infection than in the group with lupus flare $(p=0.015$, table 1$)$. Westergren ESR increased in $89 \%$ of the groups with viral and non-viral infection and in all members of the group with lupus flare. There was no difference between the Westergren ESRs of the groups with viral and nonviral infection and lupus flare during the early

Table 1 Baseline data of 19 patients with systemic lupus erythematosus (SLE) during the early febrile period. Results are shown as means (SD)

\begin{tabular}{llllll}
\hline Group & $\begin{array}{l}\text { Sex } \\
(M: F)\end{array}$ & Age & $\begin{array}{l}\text { White cell count } \\
\left(10^{9} / \mathrm{l}\right)\end{array}$ & ESR (mm/1st h) & CRP $(\mathrm{mg} / \mathrm{l})$ \\
\hline Non-viral infection $(\mathrm{n}=9)$ & $1: 8$ & $25.6(13)$ & $12.9(8.8)^{\star}$ & $82.0(27.7)$ & $73.7(78.6)$ \\
Viral infection (n=3) & $1: 2$ & $25.7(3.5)$ & $5.7(4.9)$ & $60.0(49.8)$ & $39.7(21.5)$ \\
Lupus flare (n=7) & $0: 7$ & $33(8.2)$ & $3.9(1.4)$ & $97.7(31.5)$ & $54.7(61.3)$ \\
Controls (n=11) & $1: 10$ & $43.2(13.7)$ & - & - & -
\end{tabular}

${ }^{\star} \mathrm{p}=0.015$ compared with the group with lupus flare.

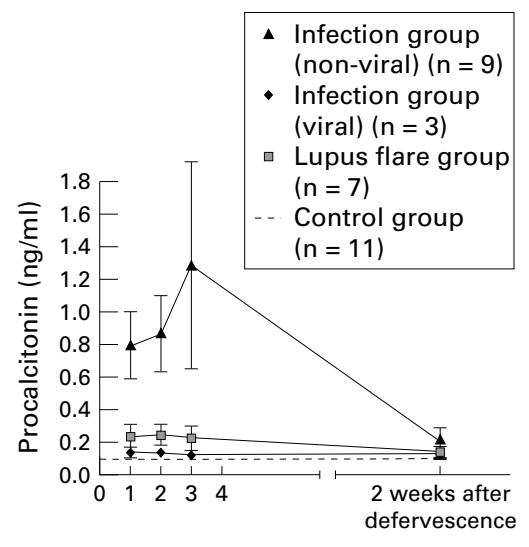

Day starting from febrile episode

Figure 1 Mean procalcitonin levels during and after febrile episode. Bars denote standard error.

febrile period $(\mathrm{p}=0.32)$. CRP increased in $92 \%$ of the group with infection and $89 \%$ of the group with lupus flare. CRP tended to be higher in the group with non-viral infection than in the groups with viral infection or lupus flare, but this did not reach significance $(\mathrm{p}=0.98)$

Serum PCT in the group with non-viral infection tended to increase continuously or rise gradually in the early febrile period (fig 1). Serum PCT levels in the early febrile period were significantly higher in the group with non-viral infection (mean (SD), 0.98 $(0.12) \mathrm{ng} / \mathrm{ml}$ ) than in the group with viral infection $(0.13(0.04) \mathrm{ng} / \mathrm{ml}, \mathrm{p}<0.01)$, the group with lupus flare $(0.24(0.18) \mathrm{ng} / \mathrm{ml}$, $\mathrm{p}<0.01)$, and the controls $(0.12(0.03) \mathrm{ng} / \mathrm{ml}$, $\mathrm{p}<0.01)$. There was no statistical difference in the PCT levels of the groups with viral infection or lupus flare and the control group $(\mathrm{p}=0.12)$. After defervescence the serum PCT level was $0.21(0.18), 0.13(0.04), 0.14$ $(0.08) \mathrm{ng} / \mathrm{ml}$ in the group with non-viral infection, the group with viral infection, and the group with lupus flare, respectively. None of the values were significantly different from the control group $(\mathrm{p}=0.86,0.49,0.58$, respectively)

New serological markers to distinguish lupus flare from infection have been investigated in an attempt to differentiate infection with lupus flare. Serum PCT is normally almost undetectable $(<0.1 \mathrm{ng} / \mathrm{ml})$ and not influenced by kidney function. Dandona et al found that after injecting endotoxin intravenously, PCT increased suddenly at six hours and maintained a plateau for more than 24 hours. ${ }^{5}$ Recently, the stimulation of peripheral blood mononuclear cells with lipopolysaccharide was found to increase PCT mRNA transcription. ${ }^{6}$ PCT levels in autoimmune disease were first studied by Eberhard et al, who showed that the PCT increased in vasculitic patients with infection $(1.93(1.19)$ $\mathrm{ng} / \mathrm{ml}$ ) and decreased after control of the infection $(0.63(0.62) \mathrm{ng} / \mathrm{ml}){ }^{7}$ PCT did not increase in patients with Wegener's granulomatosis upon disease aggravation but increased with combined infection. ${ }^{8}$

Our study is the first to observe serum PCT changes in lupus patients with fever and defervescence prospectively. In our study lupus patients with bacterial or fungal infection had higher serum PCT levels than those with viral infections and a higher level than the controls. We tried to determine the serum PCT changes during the febrile period by measuring serial samples. Serum PCT in the group with non-viral infection tended to increase continuously or rise gradually in the early febrile period (fig 1). The PCT values varied among the non-viral group and serious infections, such as aspergillus pneumonia, showed higher values than urinary infection or sinusitis (data not shown). The pitfalls of PCT as a marker for infection are that it may not increase or increase only slightly in viral infection. Our study showed that there was no difference between the serum PCT of the group with viral infection and the control group.

CRP is useful for detecting and differentiating infections in lupus. ${ }^{9} \mathrm{CRP}$ rises earlier and is more sensitive than ESR. In this study, CRP tended to increase in the case of non-viral infection, compared with viral infection or lupus flare, but this did not reach statistical significance. Our results indicate that during the early febrile period, serum PCT increased significantly in patients with SLE with non-viral infection compared with patients with lupus flare. Serum PCT decreased after defervescence. These results suggest that serum PCT helps in detecting bacterial or fungal infections during the early febrile period in SLE.

We are indebted to Bukyung Co and Miss Kyung Hee Lee for their help during this study.

This study was supported by a grant from Seoul National University, Clinical Research Institute, Institute of Allergy and Clinical Immunology.

K C SHIN Y J LEE $S$ W KANG H J BAEK

E B LEE

H A KIM

Y W SONG

Department of Internal Medicine, Clinical Reseach Institute,

Seoul National University College of Medicine, Seoul, Korea

Correspondence to: Dr Y W Song, Department of Internal Medicine, Seoul National University College of Medicine, Chongro-ku, Yongon-dong 28, Seoul 110-744, Korea ysong@plaza.snu.ac.kr

1 Kraus A. Fever in systemic lupus erythematosus. In: Klippel JH, Dieppe, eds. Rheumatology. 2nd ed. Barcelona: Mosby, 1998:7.8.3.

2 Assicot M, Gendrel D, Carsin H, Raymond J, Guilbaud J, Bohuon C. High serum procalcitonin concentrations in patients with sepsis and infection. Lancet 1993;341:515-18.

3 Karzai W, Oberhoffer M, Meier-Hellmann A, Reinhart K. Procalcitonin-a new indicator of the systemic response to severe infections. Infection 1997;25:329-34.

4 Bombardier C, Gladman DD, Urowitz MB, Caron D, Chang CH. Derivation of SLEDAI. Arthritis Rheum 1992;35:630-40.

5 Dandona P, Nin D, Wilson MF, Aljada A, Love $\mathrm{J}$, Assicot $\mathrm{M}$, et al. Procalcitonin increase after endotoxin injection in normal subjects. J Clin Endocrinol Metab 1974;79:1605-8.

6 Oberhoffer M, Stonans I, Russwurm S, Stonane E, Vogelsang H, Junker U, et al. Procalcitonin 
expression in human peripheral blood mononuclear cells and its modulation by lipopolysaccharides and sepsis-related cytokine

7 Eberhard OK, Haubitz M, Brunkhorst FM, Kleim V, Koch KM, Brunkhorst R. Usefulness of procalcitonin for differentiation between activity of systemic autoimmune disease (systemic lupus erythematosus/systemic antineutrophil cytoplasmic antibody-associated vasculitis) and invasive bacterial infection. Arthritis Rheum 1997;40:1250-6.

8 Moosig F, Csernok E, Reinhold-Keller E, Schmitt W, Gross WL. Elevated procalcitonin levels in active Wegener's granulomatosis. Rheumatol 1998;25:1531-3.

9 Hind CRK, NG SC, Feng PH, Pepys MB Serum C-reactive protein measurement in the Serum C-reactive protein measurement in the patients with systemic lupus erythematosus. Ann Rheum Dis 1985;44:260-1.

\section{Effect of daily corticosteroid treatment on CRP response to hip or knee replacement in patients with RA}

Serum $C$ reactive protein (CRP) is an acute phase reactant which may be continuously increased in patients with persistently active rheumatoid arthritis (RA), ${ }^{1}$ or raised only temporarily to a high concentration for a few days as a normal response to uncomplicated hip or knee replacement in patients with osteoarthritis or RA. ${ }^{23}$ CRP usually decreases in patients with RA when inflammatory activity is treated with daily low dose corticosteroid. This prompts the question whether the CRP response to hip or knee replacement is decreased in patients with RA taking a daily low dose of oral corticosteroid compared with those not taking corticosteroid. This is an important issue because CRP is used as an index to indicate postoperative complications. In this letter we compare the CRP response to hip or knee replacement in two groups of patients with RA: those taking and those not taking oral low dose corticosteroid.

Sixty patients ( 47 women, 13 men) fulfilling the American Rheumatism Association 1987 criteria for RA, ${ }^{4}$ treated at the Rheumatism Foundation Hospital, Heinola, in 1999, underwent hip or knee replacement. Fifty two patients were seropositive. The group receiving prednisolone comprised 44 patients, mean age 62 (SD 8.5) years. The prednisolone doses were as follows: four patients received $<5 \mathrm{mg}$ daily, $37 \mathrm{had} 5-10$ $\mathrm{mg}$ daily, and three had $12.5-30 \mathrm{mg}$ daily. The patient group not receiving prednisolone comprised 16 patients, mean age 59 (13.4) years.

The CRP concentration was measured by the Randox, United Kingdom, immunoturbidimetric assay. The magnitude of the CRP response was measured by assessing the difference between measurements taken preoperatively and during the first one to two days postoperatively (the time of the peak CRP level ${ }^{3}$ ) in both patient groups. The CRP responses in the respective groups were compared and statistically evaluated with the Mann-Whitney $U$ test. In the group not receiving prednisolone the preoperative median CRP level was 12 (interquartile range (IQR) $5-26) \mathrm{mg} / \mathrm{l}$, and at day 1 or 2 postoperatively the median CRP had risen to 80 (IQR 53-112) $\mathrm{mg} / \mathrm{l}$. In the group in which patients were taking prednisolone the preoperative median was 14 (IQR 6-38) $\mathrm{mg} / \mathrm{l}$, the

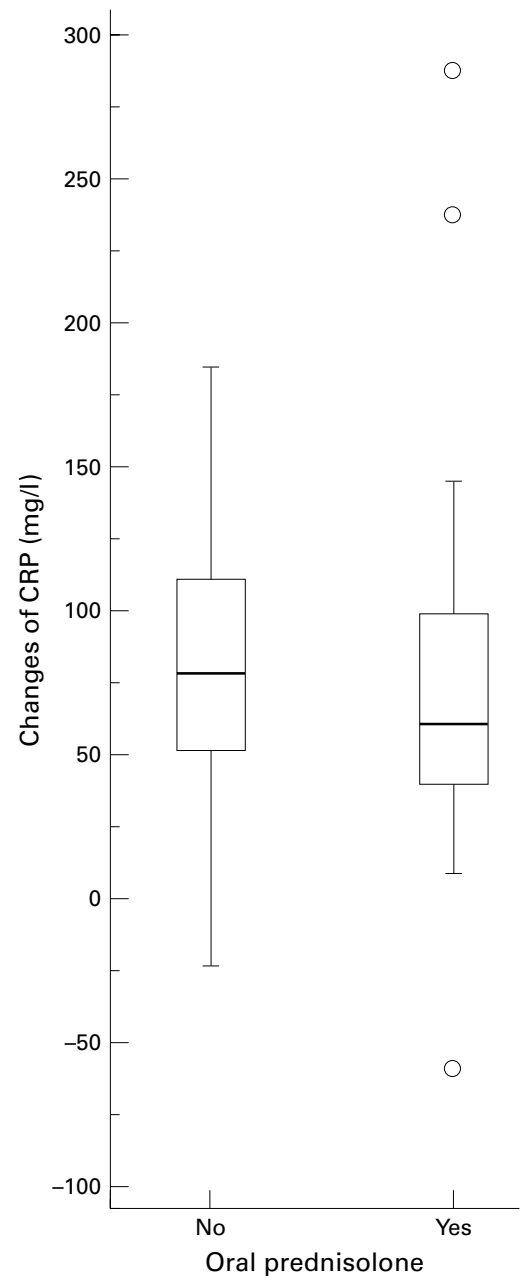

Figure 1 Box and whisker plots show the postoperative $C$ reactive protein $(C R P)$ response to hip or knee replacement in 16 patients with $R A$ not receiving prednisolone and 44 patients with $R A$ receiving continuous prednisolone.

postoperative median 62 (IQR 41-100) mg/l. The difference in CRP response to the operation between the groups was not significant, $p=0.15$ (fig 1 ). None of the patients had bacterial infection or substantial haematoma after the operation.

The rise in CRP concentration in response to hip or knee replacement was slightly, but not significantly, smaller in patients with RA receiving than in those not receiving prednisolone. Increased CRP concentration was a normal phenomenon in the first few days after hip or knee replacement in these patients with RA and was not altered by low dose prednisolone treatment. This study affords no information as to the CRP response in the presence of postoperative complications, because no such case was encountered. However, we recommend further measures if the CRP concentration remains raised for several days postoperatively and does not decrease steadily.

K LAIHO
E BELT
H MÄENPÄÄ
H KAUTIAINEN
M KAUPPI
Rheumatism Foundation Hospital,
Heinola, Finland

Correspondence to: $\mathrm{Dr} \mathrm{K}$ Laiho, Rheumatism Foundation Hospital, FIN-18120 Heinola, Finland markku.kauppi@reuma.fi

1 Dixon JS, Bird HA, Sitton NG, Pickup ME, Wright V. C-reactive protein in the serial assessment of disease activity in rheumatoid arthritis. Scand J Rheumatol 1984;13:39-44.

2 Larsson S, Thelander U, Friberg S. C-reactive protein (CRP) level after elective orthopedic surgery. Clin Orthop 1992;275:237-42

3 Laiho K, Mäenpää H, Kautiainen H, Kauppi $M$, Kaarela K, Lehto M, et al. Rise in serum C reactive protein after hip and knee arthroplasties in patients with rheumatoid arthritis. Ann Rheum Dis 2001;60:275-7.

4 Arnett FC, Edworthy SM, Bloch DA, McShane DJ, Fries JF, Cooper NS, et al. The American Rheumatism Association 1987 revised criteria for the classification of rheumatoid arthritis.
Arthritis Rheum 1988;31:315-24.

\section{Lumbar spondylodiscitis secondary to Enterobacter cloacae septicaemia after extracorporeal shock wave lithotripsy}

Infections of the lumbar spine may affect either the intervertebral disc or the vertebral body. Most infections of the intervertebral disc occur as an extension of vertebral osteomyelitis or direct inoculations during diagnostic or surgical procedures, or include urinary tract infections and septicaemia. This paper reports a case of L5-S1 spondylodiscitis secondary to Enterobacter cloacae septicaemia after extracorporeal shock wave lithotripsy (ESWL).

A 52 year old man presented with side pain, pollakiuria, haematuria, and nocturia. He had been treated with ciprofloxacin for acute pyelonephritis and nephrolithiasis as an outpatient. One week later, the patient was admitted to hospital by the urology department with symptoms of left side pain, fever, chills, shaking, and dysuria. Right renal and right ureter distal lithiasis and right hydronephrosis due to the lithiasis were diagnosed. One week after ESWL the patient was sent to the physical medicine and rehabilitation clinic with chills, shaking, high fever, and low back pain complaints. Lumbar movements were found to be restricted. There was an increase in severe pain at rest. The patient could not stand or walk. No neurological deficit was present. Body temperature was $39^{\circ} \mathrm{C}$, pulse 110 beats $/ \mathrm{min}$, blood pressure $130 / 70 \mathrm{~mm} \mathrm{Hg}$, breathing 20 breaths $/ \mathrm{min}$.

Laboratory findings were as follows: haemoglobin $133 \mathrm{~g} / \mathrm{l}$, packed cell volume 0.31 , white blood cells $18 \times 10^{9} / 1$, platelets $316 \times 10^{9} / 1$, erythrocyte sedimentation rate $110 \mathrm{~mm} / 1 \mathrm{st} \mathrm{h}$, antistreptolysin O $25 \mathrm{IU}, \mathrm{C}$ reactive protein $12.3 \mathrm{mg} / \mathrm{l}$, rheumatoid factor negative. Urea was $14 \mathrm{mmol} / \mathrm{l}$ of urea, creatinine $170 \mu \mathrm{mol} / \mathrm{l}$. Glucose and electrolytes were normal and serum aspartate aminotransferase was $80 \mathrm{U} / 1$, serum alanine aminotransferase $44 \mathrm{U} / 1$, lactate dehydrogenase 321 $\mathrm{U} / 1$, total bilirubin $22 \mu \mathrm{mol} / 1$, direct bilirubin $10 \mu \mathrm{mol} / 1$. A considerable number of leucocytes and erythrocytes were noticed in urine microscopy. Enterobacter cloacae was isolated from blood and urine. The isolated pathogen was sensitive to ceftriaxone and amikacin. 

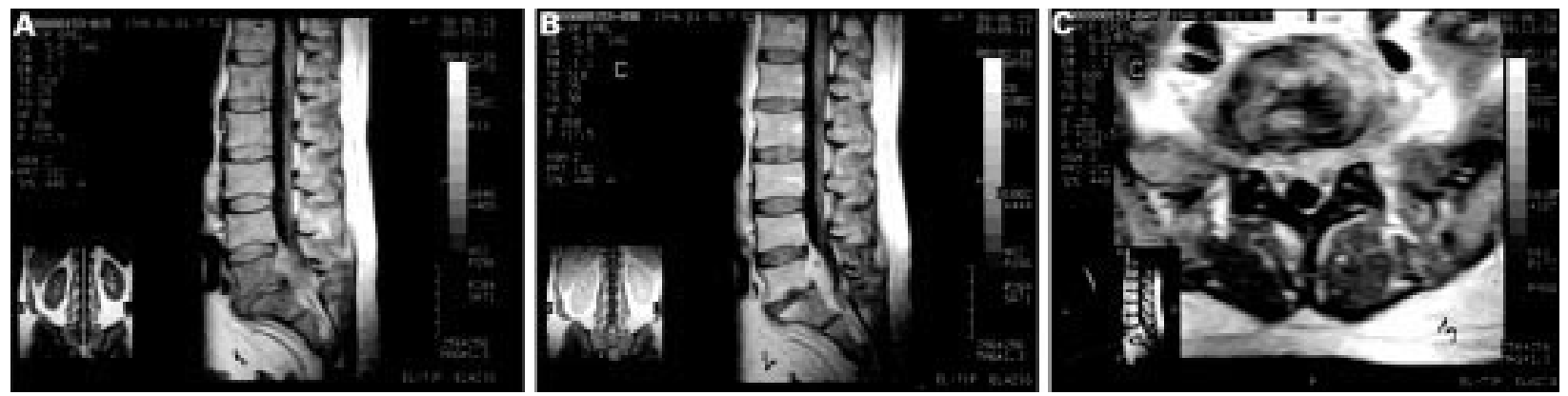

Figure $1(A, B)$ Magnetic resonance imaging findings, obtained two weeks after Enterobacter cloacae septicaemia are as follows: inflammation in the L5-S1 intervertebral disc and adjacent vertebral corpuses, decreased height of intervertebral disc, and destruction of adjacent vertebral corpus end plates. The signal intensity of the intervertebral disc and adjacent vertebral corpuses is oedematous. Inflammatory soft tissue component, extending to perivertebral region and spinal epidural space causing neuronal compression or irritation, or both. (C) Contrast enhanced mid-sagittal slice shows enhancement in the L5-S1 intervertebral disc, adjacent vertebral corpus medullary bone, and inflammatory soft tissue component.

Figure 1 shows magnetic resonance imaging (MRI) pictures obtained two weeks after the septicaemia.

Amikacin (1500 mg/day) and indometacin (150 mg/day) were given, but amikacin was stopped because nephrotoxicity developed after seven days of treatment. Later, ceftriaxone $2 \mathrm{~g}$ twice a day was given for one week, and then maintained at $1 \mathrm{~g}$ /day for three months. The patient used a lumbosacral support.

The clinical and laboratory findings of the patient improved and pain was relieved after a two month rehabilitation programme. The control MRI findings obtained 27 months later shown degeneration of the L5-S1 intervertebral disc and adjacent vertebral corpus end plates. Grade 1 spondylolisthesis is the sequel to the infection. Lumbar spondylodiscitis has not recurred after two years' follow up.

Staphylococcus aureus is reported as the major agent of spondylodiscitis. Streptococcus viridans, Streptococcus pyogenes, Salmonella spp, Enterococcus spp, Pseudomonas aeruginosa, and Brucella spp are other possible causative agents. In most cases, isolation of an agent is difficult. In a limited number of cases an agent may be isolated in biopsy materials or in blood.

We found two reported cases of spondylodiscitis caused by Enterobacter cloacae. ${ }^{2} 3 \mathrm{Gen}-$ erally, $S$ aureus is the causative agent. However, Salmonella enteritidis, ${ }^{5}$ Candida albicans, ${ }^{6}$ Streptococcus spp, ${ }^{7}$ and Enterococcus spp $^{8}$ are rare isolated pathogens. In our case, acute pyelonephritis was diagnosed before spondylodiscitis. Furthermore, worsening of the symptoms after ESWL seems important. Haematoma, contusion, petechial haemorrhagic focuses in the liver are reported as side effects of ESWL. ${ }^{9}$ Whether the spine infection was present before lithotripsy is not clear to us. There was insufficient time between the lithotripsy and diagnosis of the spine infection. Thus we think that the infection was present before the lithotripsy. ESWL may cause the spread of vertebral osteomyelitis or acceleration of sepsis. Because the case seems to originate through the haematogenous route, it may be more appropriate to state that it represents an extension of vertebral osteomyelitis.

Spinal infections should always be considered in severe back and lumbar pain. ${ }^{10}$ The patients should be monitored in a clinical and laboratory setting after invasive therapeutic procedures. Prophylactic antibiotic treatment should be given in an ESWL procedure.
A KAMANLI

S SAHIN

V KAVUNCU

Department of Physical Medicine and

Rehabilitation,

School of Medicine,

Firat University, Elazig, Turkey

S FELEK

Department of Clinical Microbiology and Infectious Diseases,

Firat University

Correspondence to: Dr A Kamanli, Firat Universitesi Firat Tip Merkezi, 23119 Elazig, Turkey

akamanli@hotmail.com

1 Galasko CSB. Spinal problems in children. In: Maddison PJ, Isenberg DA, Woo P, Glass DN, eds. Oxford textbook of rheumatology. 2nd ed. New York: Oxford University Press, 1998:123-6.

2 Solans R, Simeon P, Cuenca R, Fonollosa V, Bago J, Vilardel M. Infectious discitis caused by Enterobacter cloacae. Ann Rheum Dis by Enterobacter

3 Chassagne P, Mejjad O, Daragon A, Lecomte R, Le Loet X, Deshayes P. Spondylodiscitis caused by Enterobacter cloacae treated with cefixime. Presse Med 1990;19:673-4.

4 De Korvin B, Provensol T, Le Dantec P, Gautier C, Devillers A, Rolland Y, et al. Aspects and value of MRI in the diagnosis and follow-up of common microbes infectious spondylodiscitis. Apropos of 25 clinically and biologically suspected patients. J Radiol 1994;75:267-77.

5 Schuler A, Schaumann D, Manns MP, Koch KM. Lumbar spondylodiscitis caused by SalKM. Lumbar spondylodiscitis caused by Sal-
monella enteritidis. Dtsch Med Wochenschr monella enteritidis.

6 Lafont A, Olive A, Gelman M, Roca-Burniols J, Cots R, Carbonell J. Candida albicans spondylodiscitis and vertebral osteomyelitis in patients with intravenous heroin drug addiction. Repor of 3 new cases. J Rheumatol 1994;21:953-6

7 Faraj A, Krishna M, Mehdian SM. Cauda equina syndrome secondary to lumbar spondylodiscitis caused by Streptococcus milleri. Eur Spine J 1996;5:134-6.

8 Garcia F, Fernandez-Sola A, Garcia Quintana AM, Capdevila JA. Sponylodiscitis caused by Enterococcus: an unusual entity. Enferm Infec Enterococcus: an unusual entity.
Microbiol Clin 1995; 13:473-6

9 Martin TV, Sosa RE. Shock wave lithotripsy. In: Walsh PC, Retik AB, Vaughan ED, Wein AJ, eds. Campbell's urology. Philadelphia: Saunders, 1998:2735-52.

10 Ozgocmen S, Ardicoglu O. Spinal nerve root compression due to Brucella disc infection: a case report. Eur J Phys Med Rehabil 1998;8: 133-5.

\section{Rheumatic pneumonia}

Rheumatic pneumonia (RP) is a well described and poorly understood complication of acute rheumatic fever (ARF). It has been reported for more than a century and it has been traditionally associated with a high mortality rate. However, the existence and specificity of primary pulmonary lesions has remained controversial, because similar features may be seen in ARF with complicating congestive failure or uraemia. ${ }^{12}$ We report a case of RP that was successfully treated with steroids.

An 18 year old man was admitted to our hospital because of a 10 day history of fever, malaise, and dry cough. The patient had had ARF with carditis at age 7 , which resolved without sequels. A tonsillectomy was performed three years later. Since then, he had received a benzathine penicillin $G$ injection monthly until three years before his actual admission. On admission, physical examination disclosed a temperature of $38.5^{\circ} \mathrm{C}$, respiratory rate of $26 / \mathrm{min}$, and rales were heard at the left lower lung. The rest of the examination was unremarkable.

Laboratory values were white blood cells $14.3 \times 10^{9} / 1$, with $80 \%$ neutrophils and $9 \%$ band cells, haemoglobin $132 \mathrm{~g} / \mathrm{l}$, and platelets $410 \times 10^{9} / 1$. The erythrocyte sedimentation rate was $90 \mathrm{~mm} / 1 \mathrm{st} \mathrm{h}$. Urine analysis, coagulation studies, renal and hepatic function tests, and arterial blood gas value analysis during room air breathing were normal. A chest $x$ ray examination showed an ill-defined and non-homogeneous area of consolidation at the left lower lobe with a normal cardiac silhouette. As there was a clinical suspicion of pneumonia, acquired in the community, intravenous cefuroxime $(750 \mathrm{mg}$ three times a day) and oral roxithromycine (150 twice daily) were given.

On the fourth day after admission to hospital, fever and tachypnoea persisted. Consolidation of the air space in the posterior segment of the left lower lobe and pleural effusion were seen on chest $x$ ray examination and thoracic computed tomography (fig 1). Thoracentesis yielded a serous fluid containing $1.2 \times 10^{9}$ leucocytes/1, with $70 \%$ neutrophils, glucose $1.4 \mathrm{mmol} / \mathrm{l}$, protein $27 \mathrm{~g} / \mathrm{l}$,

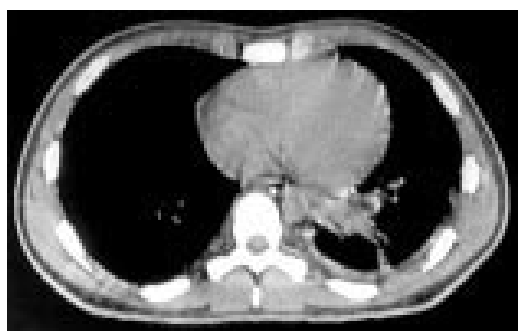

Figure 1 Computed tomography scan of the chest showing consolidation in the left lower lobe with associated pleural effusion. 
and lactate deyhdrogenase 477 IU/1. Doppler echocardiography showed a posterior pericardial effusion without any other abnormality. Bronchoscopic examination showed inflammatory changes in left lower bronchi. There were no neoplastic cells in bronchoalveolar lavage specimens. Repeated serological tests for Mycoplasma pneumoniae, Chlamydia pneumoniae, Legionella species, cytomegalovirus, and Epstein-Barr virus were negative. Tests for antineutrophil cytoplasmic antibodies, rheumatoid factor, and antinuclear antibodies were negative, and the serum level of angiotensin converting enzyme was normal.

On the 14th day after admission to hospital the patient developed arthritis at the left knee and the right wrist. Arthrocentesis showed a turbid fluid which contained $15.2 \times 10^{\circ}$ leucocytes/l and glucose $1.3 \mathrm{~g} / \mathrm{l}$; no crystals were seen. Titres of antistreptolysin $\mathrm{O}$ and $\mathrm{C}$ reactive protein were 400 Todd units (normal $<200$ ) and $1.20 \mathrm{~g} / \mathrm{l}$, respectively. Blood, sputum, pleural fluid, bronchoalveolar lavage, and joint effusion repeated cultures were negative, and no acid fast bacilli were seen.

The antibiotic treatment was discontinued and acetylsalicylic acid (1.5 g four times a day) was started. A dramatic improvement in fever and arthritis occurred, though the radiological lesion remained unchanged. A histological lung specimen obtained by thoracoscopy showed inflammatory changes with thickness and fibrosis of alveolar septa, and nodular aggregates of mature lymphocytes. No micro-organism was seen or cultured in tissue specimens. Prednisone $60 \mathrm{mg}$ daily was substituted for aspirin. The radiological lesion improved progressively, and antistreptolysin $\mathrm{O}$ and $\mathrm{C}$ reactive protein normalised. Corticosteroid treatment was tapered over two months without any further relapse, and prophylaxis with benzathine penicillin G monthly was resumed. In a 24 month follow up period the patient remained asymptomatic.

For unknown reasons, in the past decades there has been a decline in the incidence and severity of rheumatic fever in developed countries. ${ }^{3}$ Thus unusual complications, such as $\mathrm{RP}$, are a challenging diagnosis for clinicians without experience of this illness. To the best of our knowledge, only six isolated case reports have been reported in English or Spanish over the past 20 years (table 1). ${ }^{4}$

Pulmonary disease may occur in both the first and recurrent attacks of ARF, either as part of the rheumatic process, or secondary to the cardiac lesion, congestive heart failure, uraemia or intercurrent infection. ${ }^{2}$ The incidence of pulmonary disease in ARF has greatly varied $(2-60 \%)$ depending on the rigidity of the criteria used and the nature of the series. ${ }^{12}$ The clinical spectrum of RP varies from a mild to a fulminant course. Dyspnoea and non-productive cough are the most commonly reported symptoms. ${ }^{12}$ Multiple radiological patterns have been described, including consolidation, diffuse bilateral and migratory infiltrates, pleural effusion, and confluent nodular lesions. ${ }^{14}$ A pathological examination shows no unique lung lesions in $\mathrm{ARF}$, and the most commonly reported pulmonary findings have been alveolar haemorrhage, acute bronchopneumonia, organising fibrinous oedema, interstitial inflammatory exudates, inflammation and necrosis of septa, arteriolitis, and globular tufts of intraalveolar fibrous tissue, so-called Masson bodies. ${ }^{10}$ It may be difficult to separate the contribution of the heart failure or uraemia to the RP by itself. ${ }^{1210}$ Because of the lack of specific criteria, RP remains an exclusion diagnosis.

Our patient satisfied the updated Jones criteria for the diagnosis of ARF. ${ }^{3}$ The absence of response to antimicrobial treatment, the histological findings, and the response to anti-inflammatory treatment favoured a diagnosis of RP. Despite the fact that salicylates have been advocated in the management of $\mathrm{RP},{ }^{68}$ steroids seems to be the most suitable treatment. None the less, deaths have occurred despite the use of this treatment. ${ }^{59}$

J DE LA FUENTE A NODAR B SOPEÑA C A MARTÍNEZ

Department of Internal Medicine, Unit of Infectious Diseases, Xeral-Cies Hospital, Vigo,

University of Santiago de Compostela, Spain

A FERNÁNDEZ

Division of Respiratory Medicine

Correspondence to: Dr J de la Fuente Aguado, Nicaragua $10,3^{\circ}$ B, 36203 Vigo, Spain

1 Lustok MJ, Kuzma JF. Rheumatic fever pneumonitis: a clinical and pathologic study of 35 cases. Ann Intern Med 1956;44:337-57.

2 Brown G, Goldring D, Behrer MR. Rheumatic pneumonia. J Pediatr 1958;52:598-619.

3 American Heart Association. Guidelines for the diagnosis of rheumatic fever. Jones Criteria, diagnosis of rheumatic fever. JAMA 1992;268:2069-73.

4 Burgert SJ, Classen DC, Burke JP, Veasy LG.

Rheumatic pneumonia: reappearance of a previously recognized complication of acute rheumatic fever. Clin Infect Dis 1995;21:1020-2.

5 Serlin SP, Rimsza ME, Gay JH. Rheumatic pneumonia: the need for a new approach. Pediatrics 1975;56:1075-8.

6 Marti García JL, Candel Delgado JM, Guijarro Morales A, Mateos Muller J, Martín Navajas JA. Neumonitis reumática. Rev Clin Esp 1975; 136:551-3.

7 Raz I, Fisher J, Israeli A, Gottehrer N, Chisin R, Kleinman Y. An unusual case of rheumatic pneumonia. Arch Intern Med 1985;145: pneumon.

8 Yamamoto LG, Seto DSY, Reddy DV. Pneumonia associated with acute rheumatic fever. Clin Pediatr 1987;26:198-200.

9 Ephrem D. Rheumatic pneumonia in a 10-year old ethiopian child. East Afr Med J 1990;67: $740-2$

10 Grunow WA, Esterly JR. Rheumatic pneumonitis. Chest 1972;61:298-301.

\section{Referrals to an "early synovitis clinic": are they appropriate?}

There is mounting evidence that early disease modifying treatment improves the outcome in patients with rheumatoid arthritis (RA) and that treatment should begin before the disease is established and irreversible damage has occurred. ${ }^{2}$ This evidence has led to the development of "early synovitis clinics" in many rheumatology units to fast track appropriate patients. Early referral for specialist advice has been shown to be associated with improved health and physical function, with the concept of early treatment of RA shortening observation periods before referral in general practice. ${ }^{3}$ A shortened observation time is important as Irvine et al showed that $73 \%$ of patients waiting more than one year from the onset of symptoms already had radiological evidence of erosive change. ${ }^{4}$

Despite the improved observation times, there are few published data showing whether referrals to early synovitis clinics are appropriate. We reviewed all referrals $(n=156)$ to our early synovitis clinic at the Royal Victoria Hospital, Belfast, which was established in January 1999 , to determine the proportion which were appropriate. Referrals were considered appropriate if they could be classified within a broad based category of inflammatory arthritis. We felt a broad based approach was necessary to identify patients with RA early in the disease course. Referral guidelines to the early synovitis clinic were circulated to all general practitioners in the catchment area of the hospital (population 600 000) every three months. The information was also disseminated by the local medical press and by presentations at general practitioner meetings.

Fifty four per cent $(n=84)$ of the 156 patients were classified as having inflammatory arthritis. Of these patients, 33 were diagnosed as RA and disease modifying treatment was started. The other diagnoses within the inflammatory arthritis group included psoriatic arthritis, reactive arthritis, ankylosing spondylitis, seronegative arthritis, systemic lupus erythematosus, primary Sjögren's syndrome, and crystal arthritis. Despite the educational strategies outlined above, a large percentage of referrals were inappropriate. Forty six per cent $(n=72)$ of patients did not have inflammatory arthritis. Of these patients, 35 had fibromyalgia, 28 had osteoarthritis, and nine had another diagnosis within the category of soft tissue rheumatism.

The median time from symptom onset to referral was eight weeks and the median time from arrival of the referral letter to attendance at the early arthritis clinic was four weeks. These results suggest that although the message about early referral appears to have been successful there were a large number of inappropriate referrals.

Table 1 Summary of cases reports of rheumatic pneumonia over the past two decades

\begin{tabular}{|c|c|c|c|c|c|c|}
\hline Reference & Age/sex & Previous ARF & Major criteria & Cardiac failure & Treatment & Outcome \\
\hline 5 & $13 / \mathrm{M}$ & No & Carditis & Yes & Hydrocortisone & Died \\
\hline 6 & $14 / \mathrm{F}$ & Yes & Carditis & Yes & Pyrazolidine & Favourable \\
\hline 7 & $14 / \mathrm{M}$ & Yes & $\begin{array}{l}\text { Carditis } \\
\text { Arthritis }\end{array}$ & Yes & $\begin{array}{l}\text { Aspirin (initial) } \\
\text { Prednisone }\end{array}$ & Favourable \\
\hline 8 & $10 / M$ & No & Carditis & No & Aspirin & Favourable \\
\hline 9 & $10 / \mathrm{F}$ & No & $\begin{array}{l}\text { Carditis } \\
\text { Arthritis }\end{array}$ & Yes & $\begin{array}{l}\text { Salicylates (initial) } \\
\text { Steroid }\end{array}$ & Died \\
\hline 4 & $19 / M$ & No & $\begin{array}{l}\text { Carditis } \\
\text { Arthritis }\end{array}$ & Yes & Prednisone & Favourable \\
\hline Present report & $18 / \mathrm{M}$ & Yes & $\begin{array}{l}\text { Carditis } \\
\text { Arthritis }\end{array}$ & No & $\begin{array}{l}\text { Aspirin (initial) } \\
\text { Prednisone }\end{array}$ & Favourable \\
\hline
\end{tabular}


Factors contributing to inappropriate referrals include:

- The low priority of musculoskeletal disorders in undergraduate training, ${ }^{5}$ resulting in poor skills in recognising signs and symptoms of inflammatory arthritis

- The opportunity for faster access to a specialty with long waiting lists

- The broad based referral guidelines which were designed to obtain maximum sensitivity for patients with early RA.

To maximise valuable clinic time for patients with early RA and improve the proportion of appropriate referrals we suggest that increased emphasis should be given to the importance of recognition of inflammatory arthritis in undergraduate and postgraduate medical education. The exploration of new methods of triage in primary care groups by general practitioners with a special interest in rheumatology, or by specialist rheumatology nurses, may also help to improve referrals.

P A COURTNEY G D WRIGHT

Department of Rheumatology, Royal Victoria Hospital, Belfast, N Ireland

Correspondence to: Dr P Courtney, Department of Rheumatology, Musgrave Park Hospital, Stockman's Lane, Belfast BT9 7JB, N Ireland

p.pa.courtney@talk21.com

1 Egsmose C, Lund B, Borg G, Pettersson H, Berg E, Brodin U, et al. Patients with rheumatoid arthritis benefit from early 2nd lin therapy: 5 year follow up of a prospective double blind placebo controlled study. J Rheumatol 1995;22:2208-13.

2 Stenger AAME, van Leeuwen MA, Houtman PM, Bruyn GA, Speerstra F, Barendsen BC, $e$ al. Early effective suppression of inflammation in rheumatoid arthritis reduces radiological progression. Br J Rheumatol 1998;37:115763.

3 Houssien DA, Scott DL. Early referral and outcome in rheumatoid arthritis. Scand J Rheumatol 1998;27:300-2.

4 Irvine S, Munro R, Porter D. Early referral, diagnosis, and treatment of rheumatoid arthritis: evidence for changing medical pracarthritis: evidence for changing medic

5 Doherty M, Abawi J, Pattrick M. Audit of medical inpatient examination: a cry from the joint. J R Coll Physicians Lond 1990;24:115-18.

\section{Anti-dsDNA antibodies associated with acute EBV infection in Sjögren's syndrome}

The role of viral infection in the pathogenesis of autoimmune diseases is not clear. Some authors have suggested a role for herpes viruses and retroviruses in the pathogenesis of systemic rheumatic diseases, ${ }^{1-4}$ whereas others have produced evidence against this idea. $^{5-7}$ In this report we present a case in which an association was found between Epstein-Barr virus (EBV) infection and antiDNA antibodies in a patient with Sjögren's syndrome.

A 28 year old woman was diagnosed with Sjögren's syndrome. The clinical presentation included diffuse myalgias, tiredness, and intermittent respiratory complaints. Electrophoresis showed polyclonal hypergammaglobulinaemia. Antinuclear antibody testing by indirect immunofluorescence on HEp-2 cells (Immunoconcepts, Sacramento, CA) showed a fine speckled nuclear pattern. The antibodies were identified as anti-Ro/SS-A antibodies by counterimmunoelectrophoresis. $^{8}$ No anti-double stranded DNA (antidsDNA) antibodies were present (Crithidia luciliae assay; Immunoconcepts). Four years after the diagnosis of Sjögren's syndrome, the patient had an acute EBV infection with persistent tiredness, icterus, and hepatosplenomegaly. The EBV infection was documented by positive heterophile antibodies and the presence of $\operatorname{IgM}$ (titre 1/32) and IgG (titre 1/256) antibodies to EBV viral capsid antigen. The antibodies to early antigens were negative $(<1 / 8)$. The patient did not have $\operatorname{IgM}$ rheumatoid factor, which excluded the possibility of a false positive $\operatorname{Ig} M$-viral capsid antigen test induced by the presence of rheumatoid factor. Neither antiviral capsid antigen antibodies nor anti-early antigen antibodies had been found one year before the patient presented with the EBV infection. The Crithidia luciliae test was negative two months before the EBV infection. Three months and eight months after the acute infection, respectively, the Farr assay (Ortho Clinical Diagnostics, Amersham, UK) and the Crithidia luciliae assay disclosed antidsDNA antibodies. The patients showed no progressive disease and did not develop signs of systemic lupus erythematosus.

The association between EBV and antidsDNA antibodies in the case presented here indicates a possible role of the virus in the generation of anti-dsDNA antibodies. The formation of anti-dsDNA autoantibodies may result from the activation of specific $B$ lymphocyte clones or from an imbalance in the regulation of the immune system due to EBV infection. This is consistent with the finding that EBV transformed B cells can produce IgG antibodies with specificity for dsDNA, ${ }^{9}$ and with the suggestion that EBV infection may be a causative factor in lupus. ${ }^{11}$
E Y PADALKO

$\mathrm{X}$ BOSSUYT

Laboratory Medicine, Immunology, University Hospitals Leuven, Herestraat 49,

3000 Leuven, Belgium

Correspondence to: Dr Bossuyt

This work was presented at the 52nd AACC annual meeting, San Francisco, CA in June 2000 and has been published in abstract form in Clin Chem 2000;46(suppl 6):A44.

1 Miyasaka N, Yamaoka K, Tateishi M, Nishioka $\mathrm{K}$, Yamamoto $\mathrm{K}$. Possible involvment of Epstein-Barr virus (EBV) in polyclonal B-cell activation in Sjögren's syndrome. J Autoimmun 1989;2:427-32.

2 Haruta J, Saito I. Possible involvement of Epstein-Barr virus in the pathogenesis of Sjögren's syndrome. Nippon Rinsho 1995;53: 2479-83.

3 Karameris A, Gorgoulis V, Iliopoulos A, Frangia $\mathrm{C}$, Kontomerkos T, Ioakeimidis D, et al. Detection of the Epstein-Barr viral genome by an in situ hybridization method in salivary gland biopsies from patients with secondary Sjögren's syndrome. Clin Exp Rheumatol 1992; 10:327-32.

4 Tsubota K, Fujishima H, Toda I, Katagiri S, Kawashima Y, Saito I. Increased levels of Epstein-Barr virus DNA in lacrimal glands of Siögren's syndrome patients. Acta Ophthalmol Sjögren's syndrome pati

5 Merne ME, Syrjanen SM. Detection of EpsteinBarr virus in salivary gland specimens from Sjögren's syndrome patients. Laryngoscope 1996;106:1534-9.

6 Venables PJ, Roffe LM, Erhardt CC, Maini RN, Edwards JM, Porter AD. Titers of antibodies to RANA in rheumatoid arthritis and normal sera. Relationship to Epstein-Barr virus infection. Arthritis Rheum 1981;24:1459-68.

7 Venables PJ, Baboonian C, Horsfall AC, Halliday D, Maini RN, Teo CG, et al. The response to Epstein-Barr virus infection in Sjögren's syndrome. J Autoimmun 1989;2:439-48.

8 Walravens MJF, Vanherrewegen $\mathrm{H}$, Lacquet F, Godefridis G, Korevits G, Stevens E, et al. Counterimmunoelectrophoresis with serum prediffusion: an improved method for the prediffusion: an improved method for the detection and identification of antibodies against extractable nuclear and cytoplasmic antigens. J Immunol Methods 1996;201:89

9 Takai O, Sasaki T, Muryoi T, Tamate E, Yoshinaga K, Sano H. Epstein-Barr virustransformed B cells bearing idiotypes of anti-DNA autoantibodies. J Clin Immunol 1988;8:193-9.

10 Warrington RJ, Wong SK, Ramdahin S, Rutherford WJ. Normal human cord blood B cells can produce high affinity IgG antibodies to dsDNA that are recognized by cord blood-derived antithat are recognized by cord blood-derived anti42:397-406.

11 Harley JB, Sestak AS, Willis LG, Fu SM, Hansen JA, Reichlin M. A model for disease heterogeneity in systemic lupus erythematosus. Relationships between histocompatibility antigens, autoantibodies and lymphopenia or renal disease. Arthritis Rheum 1989;32:413-19. 